\title{
Effects of the TLR4 transgene on reproductive traits and DNA methylation pattern of oocytes in ewes
}

\author{
Yi FANG ${ }^{1}$, Xiangwei FU' ${ }^{1}$, Junjie LI $^{2}$, Ming DU ${ }^{1}$, Baoyu JIA ${ }^{1}$, \\ Jinlong ZHANG ${ }^{3}$, Xiaosheng $\mathrm{ZHANG}^{3}$, Shien ZHU $(\bowtie)^{1}$ \\ 1 National Engineering Laboratory for Animal Breeding and Key Laboratory of Animal Genetics, Breeding and Reproduction of Ministry of \\ Agriculture, College of Animal Science and Technology, China Agricultural University, Beijing 100193, China \\ 2 College of Animal Science and Technology, Agricultural University of Hebei, Baoding 071000, China \\ 3 Animal Husbandry and Veterinary Research Institute of Tianjin, Tianjin 300412, China
}

\begin{abstract}
This study was conducted to systematically assess the reproductive performance of transgenic TLR4 ewes. In the TLR4 transgenic founders $\left(\mathrm{F}_{0}\right)$ and their positive offspring $\left(\mathrm{F}_{1}\right)$, hematological and reproductive parameters and the global DNA methylation level in oocytes at various stages were analyzed. The values of the physiological and biochemical parameters determined from the blood samples did not differ significantly between the transgenic and wild-type ewes. Moreover, the transgenic ewes showed reproductive traits similar to the wildtype ewes. These traits included characteristics of puberty, the estrus cycle, estrus duration, gestation, the pregnancy rate and the superovulation response. Additionally, no significant differences were found between transgenic and wild-type ewes in the DNA methylation level of the oocytes at various stages. In summary, the preliminary evidence presented in this paper demonstrates that the presence of the TLR4 transgene did not affect the reproductive performance in sheep.
\end{abstract}

Keywords TLR4 transgenic ewe, safety assessment, reproductive trait, oocyte, DNA methylation

\section{Introduction}

With the rapid development of transgenic technology, the number of transgenic animals has increased dramatically and has continued to grow in recent years [1]. The first established transgenic method used in livestock was the microinjection of exogenous DNA into the pronucleus of the zygote [2]. An exogenous gene may insert at a suboptimal site, altering a balanced genotype and producing unpredictable effects $[3,4]$. For this reason, careful

Received December 2, 2014; accepted December 22, 2014

Correspondence: zhushien@cau.edu.cn monitoring of the health, welfare and safety of the transgenic animal is generally advised $[3,5,6]$. Meanwhile, according to principles of the Food and Agriculture Organization (FAO) and the World Health Organization (WHO), the safety assessment of genetically modified animal is essential for market application [7]. Such monitoring is crucial for the application of transgenic technology and the use of transgenic animals for biomedical and agricultural applications, and it would be also helpful to improve the understanding of transgenic animals as well as the public acceptance of biotechnology in general [8].

Factors that may potentially affect the health of transgenic large animals have been identified, and recommendations regarding welfare assessment in various stages of transgenic programs have been published [4]. Biosafety studies on transgenic animals are becoming important and most focus on the topics of metabolism [911], microbial flora [11-13], growth performance $[8,14,15]$, genetic drift [11-13] and welfare [4,16]. However, little information on reproductive safety assessment in transgenic animals is available, and the topic is controversial. Previous studies of reproductive safety have been conducted in pigs carrying enhanced green fluorescent protein (EGFP) $[14,17]$. These studies revealed no significant differences between transgenic and wild-type pigs in puberty, gestation or litter size. However, studies in transgenic mice clearly demonstrated that certain mutations resulting from random insertions can have negative effects on reproductive performance. These effects include abnormal germ cells, early embryonic death, female infertility and male sterility [18-20]. Therefore, it is necessary to evaluate the reproductive safety of animals produced by genetic engineering.

DNA methylation is an epigenetic modification that can regulate gene expression [21]. The random insertion and expression of exogenous genes and the use of micro- 
manipulation may produce changes in DNA methylation patterns $[22,23]$. Studies have shown that genetically modified animals can have elevated levels of methylation, retarding offspring growth and causing other abnormal phenomena [24]. Abnormal methylation patterns can produce developmental blocks in oocytes and embryos. These blocks are associated with decreases in reproductive potential $[25,26]$. Therefore, the analysis of the global methylation pattern of oocytes can serve as an important indicator of reproductive performance in females. This approach will facilitate the evaluation of the animal reproductive health risks of transgenic technology. To our knowledge, studies of transgenic reproductive performance assessment from the perspective of epigenetics have not previously been reported.

TLR4 is an important Toll-like receptor in the innate immune system which responds to common Gramnegative bacterial diseases that cause harm to sheep, and indeed humans [27]. In the present study, TLR4 transgenic ewes were used as a model to assess reproductive safety by analyzing physiological and biochemical characteristics of the blood, basic reproductive traits and the DNA methylation level of oocytes at various stages.

\section{Materials and methods}

\subsection{Ethics statement}

Superovulation and blood collection were performed at the experimental station of the China Agricultural University. The entire procedure was carried out in strict accordance with the protocol approved by the Animal Welfare Committee of China Agricultural University.

\subsection{Animals}

Two generations of TLR 4 hemizygous ewes were used in this study. Five $\mathrm{F}_{0} T L R 4$ transgenic ewes had previously been produced by pronuclear microinjection and embryo transplantation. Seven $\mathrm{F}_{1}$ TLR4 transgenic ewes were obtained by breeding the male transgenic founders with wild-type female ewes. The wild-type ewes from the control group were full sibs or half sibs of a transgenic line with the same background (Small-tail Han and Dorper ewe hybrid). All ewes were raised in the same rearing environment and fed with the same fodder and commercial concentrate supplement year-round.

\subsection{Testing of blood physiological and biochemical parameters}

Measurements of blood physiological and biochemical parameters were made in 1-year-old transgenic and control ewes (blood sampling before superovulation). The physiological parameters were measured with a MEK-7222K
Hematology Analyzer (NIHON KOHDEN CORPORATION, Tokyo, Japan). The following parameters were measured: white blood cell count (WBC), red blood cell count (RBC), hemoglobin (HGB), and hematocrit (HCT). All analyses of blood plasma were performed on a TOSHIBA TBA-40 FR analyzer (Toshiba Medical Systems Corporation, Japan) using the relevant kits for each parameter. The following biochemical parameters were measured in the plasma: serum total protein, albumin, globulin, alanine aminotransferase, aspartate aminotransferase, glucose, blood urea nitrogen and triglyceride.

\subsection{Monitoring of reproductive traits}

Puberty was recorded when ewes exhibited first estrus behavior. At 18 weeks of age, teaser rams were introduced to the ewes to detect the onset of the first estrus. The teaser ram was introduced up to twice daily at 6 a.m. and 6 p.m. of each group for $1 \mathrm{~h}$. Ewes being receptive for teaser and standing for mounting by the teaser were considered in estrus. In addition, the estrus ewes also demonstrated secondary estrus behavior such as walking the fence, increased vocalization for the ram, a decrease in appetite and reddened and swollen vulva. Complete disappearance of these manifestations denoted the end of estrus. The date of onset of the first estrus was recorded for each ewe and considered as an indicator for pubertal age. Detection of estrus cycle and duration began at 10-month-old, until superovulation, the estrus cycle was considered as the interval between two consecutive estruswere. A complete estrus performance was considered as estrus duration. Pregnancy rate and gestation based on breeding records.

\subsection{Collection of in vivo oocytes}

Superovulation was performed in $4 \mathrm{~F}_{0}$ and $4 \mathrm{~F}_{1}$ ewes, all approximately 14-month-old. The ewes were randomly sampled from the transgenic individuals. The donors were treated with a CIDR (Pharmacia and Upjohn Company, Rydalmere, NSW, Australia) device and with FSH (Pharmacia \& Upjohn Company, Rydalmere, Australia). A CIDR was embedded in the vagina for recording on Day 0 . FSH was continuously injected for 4 days beginning on Day 9. The CIDR was removed on Day 12. Oocytes were then collected at various time intervals following the removal of the CIDR. The collection time points were based on the status of meiotic progression: GV, $54 \mathrm{~h}$; GVBD, $58 \mathrm{~h}$; MI, $64 \mathrm{~h}$; MII, $68 \mathrm{~h}$. The oocytes at various maturation stages were collected by different methods. Briefly, the donor sheep were anaesthetized, after opening the abdominal cavity, the ovaries were exposed outside the abdomen, and GV oocytes were then aspirated from 2 to 5 $\mathrm{mm}$ visible follicles of the ovaries with a $10 \mathrm{~mL}$ syringe equipped with an 18 gauge needle. Additional developmental stage oocytes were collected by the tubal flushing method. The donors were superovulated three times 
successively with the same procedure at one-month intervals. The cumulus cells were removed by gently pipetting in TCM-199 (Gibco-BRL, Grand Island, NY, USA) containing $0.05 \%(\mathrm{w} / \mathrm{v})$ hyaluronidase. Morphologically normal oocytes with homogeneous cytoplasm were considered suitable for further analysis and were fixed with 4\% paraformaldehyde for immunostaining experiments. The superovulation response was measured by the average number of oocyte recovery and corpora lutea.

\subsection{Immunocytochemical staining of oocytes}

Immunocytochemical staining of oocytes was used to assess DNA methylation, and DNA methylation level was reflected by fluorescence intensity. The oocytes used for staining were permeabilized with $1 \%$ Triton X-100 in PBS for $30 \mathrm{~min}$ and then treated in $2 \mathrm{~mol} \cdot \mathrm{L}^{-1} \mathrm{HCl}$ for $30 \mathrm{~min}$ at $25^{\circ} \mathrm{C}$. Non-specific binding was blocked with $0.1 \% \mathrm{BSA}$ for $30 \mathrm{~min}$ at room temperature. Incubation was then performed with anti-5-MeC antibodies (Epigentek Group Inc., NY, USA) (1:500) at $4^{\circ} \mathrm{C}$ overnight. The oocytes were then washed extensively and probed with fluorescein isothiocyanate (FITC)-conjugated anti-mouse IgG (Santa Cruz Biotechnology, Inc., TX, USA) (1:100) for $1.5 \mathrm{~h}$ at $37^{\circ} \mathrm{C}$. The DNA was visualized by counterstaining with $10 \mu \mathrm{g} \cdot \mathrm{mL}^{-1}$ propidium iodide (PI) for $10 \mathrm{~min}$. After extensive washing, the oocytes were incubated in PBS containing $10 \%$ triethylenediamine. The oocytes were then mounted on slides, and fluorescence was detected with an Olympus BX40 spectral confocal scanning microscope (Olympus Corporation, Tokyo, Japan) at excitation wavelengths of 488 and $543 \mathrm{~nm}$. The system settings were constant for all of the examinations. Each experiment was repeated at least three times, and at least 30 oocytes were used for each group.

The fluorescence intensities were quantified using FV10-ASW 3.0 Free Viewer software (Olympus, Tokyo, Japan). The pixel value of the fluorescence was measured within the nucleus area and in the same area of the cytoplasm as the nuclear region, and the cytoplasmic value was subtracted from the nuclear value.

\subsection{Statistical analyses}

All values were presented as the mean \pm standard deviation.
The data (except for the pregnancy rate) were analyzed using a one-way ANOVA combined with a least significant difference test. The pregnancy rates were analyzed using the Chi-square test. $P<0.05$ was considered significant.

\section{Results}

3.1 Blood physiological and biochemical parameters in transgenic (TG) and wild-type (WT) ewes

No significant differences were found in either the $\mathrm{F}_{0}$ or the $\mathrm{F}_{1}$ between the TG and WT ewes in four categories of physiological parameters (Table 1). Similarly, the values of the eight parameters of blood biochemistry were consistent between the TG ewes and the WT ewes in the $\mathrm{F}_{0}$ and $\mathrm{F}_{1}$ (Table 2).

\subsection{Reproductive traits in TG and WT ewes}

The results (Table 3) indicated there were no significant differences in the puberty, estrus cycle, estrus duration, gestation and total artificial fertilization pregnancy rate between the TG and WT ewes in the $F_{0}$ or $F_{1}$.

The $F_{0}$ and $F_{1}$ TG ewes showed an average number of corpora lutea and the number of recovered oocytes per TG ewe was similar to those of the WT ewes (Table 4).

\subsection{Global DNA methylation of oocytes in TG and WT ewes}

The level of DNA methylation was measured by the total $5-\mathrm{MeC}$ fluorescence in the oocytes at various stages (Fig. 1). The level of DNA methylation in the oocytes from stage GV to stage MII did not differ significantly between the $F_{0}$ and $F_{1}$ TG and WT ewes. Additionally, the trend in the variation of the level of methylation from stage GV to stage MII in the TG group was consistent with that of the WT group in the $F_{0}$ and $F_{1}$ (Fig. 2).

\section{Discussion}

A major prerequisite for the potential usage of a novel transgenic line is that animal health and welfare are not

Table 1 Physiological parameters of TG and WT ewes in $F_{0}$ and $F_{1}$

\begin{tabular}{lcccccc}
\hline \multirow{2}{*}{ Physiological parameters } & \multicolumn{3}{c}{$\mathrm{F}_{0}$} & & \multicolumn{3}{c}{$\mathrm{F}_{1}$} \\
\cline { 2 - 4 } \cline { 5 - 6 } & $\mathrm{TG}(n=5)$ & $\mathrm{WT}(n=5)$ & & $\mathrm{TG}(n=7)$ & $12.15 \pm 0.65$ \\
$\mathrm{RBC} /\left(10^{12} \cdot \mathrm{L}^{-1}\right)$ & $12.01 \pm 0.79$ & $12.32 \pm 0.45$ & & $12.22 \pm 0.48$ & $20.75 \pm 4.05$ \\
$\mathrm{WBC} /\left(10^{9} \cdot \mathrm{L}^{-1}\right)$ & $18.45 \pm 3.44$ & $20.06 \pm 3.51$ & & $17.44 \pm 2.98$ & $110.00 \pm 12.06$ \\
$\mathrm{HGB} /\left(\mathrm{g} \cdot \mathrm{L}^{-1}\right)$ & $112.79 \pm 8.88$ & $107.58 \pm 5.19$ & & $110.40 \pm 4.17$ & $34.95 \pm 4.15$ \\
$\mathrm{HCT} / \%$ & $35.15 \pm 1.28$ & $32.77 \pm 2.48$ & & $34.34 \pm 1.15$ & \\
\hline
\end{tabular}


Table 2 Biochemical parameters of TG and WT ewes in $\mathrm{F}_{0}$ and $\mathrm{F}_{1}$

\begin{tabular}{|c|c|c|c|c|}
\hline \multirow{2}{*}{ Biochemical parameters } & \multicolumn{2}{|c|}{$\mathrm{F}_{0}$} & \multicolumn{2}{|c|}{$\mathrm{F}_{1}$} \\
\hline & TG $(n=5)$ & WT $(n=5)$ & TG $(n=7)$ & WT $(n=6)$ \\
\hline $\mathrm{TP} /\left(\mathrm{g} \cdot \mathrm{L}^{-1}\right)$ & $75.19 \pm 4.41$ & $77.04 \pm 5.39$ & $78.98 \pm 6.58$ & $68.10 \pm 4.81$ \\
\hline $\mathrm{ALB} /\left(\mathrm{g} \cdot \mathrm{L}^{-1}\right)$ & $34.42 \pm 6.11$ & $37.40 \pm 2.22$ & $31.68 \pm 1.19$ & $35.90 \pm 3.34$ \\
\hline $\mathrm{GLO} /\left(\mathrm{g} \cdot \mathrm{L}^{-1}\right)$ & $35.38 \pm 1.25$ & $34.62 \pm 3.41$ & $35.90 \pm 3.30$ & $32.20 \pm 1.55$ \\
\hline $\mathrm{ALT} /\left(\mathrm{IU} \cdot \mathrm{L}^{-1}\right)$ & $15.29 \pm 3.29$ & $14.38 \pm 2.77$ & $16.67 \pm 4.12$ & $14.50 \pm 1.52$ \\
\hline $\mathrm{AST} /\left(\mathrm{IU} \cdot \mathrm{L}^{-1}\right)$ & $151.49 \pm 10.01$ & $139.47 \pm 7.09$ & $148.00 \pm 12.48$ & $133.50 \pm 7.59$ \\
\hline $\mathrm{BUN} /\left(\mathrm{mmol} \cdot \mathrm{L}^{-1}\right)$ & $6.66 \pm 0.42$ & $6.01 \pm 0.29$ & $6.60 \pm 0.23$ & $5.85 \pm 0.35$ \\
\hline $\mathrm{GLU} /\left(\mathrm{mmol} \cdot \mathrm{L}^{-1}\right)$ & $3.44 \pm 0.14$ & $3.51 \pm 0.17$ & $3.32 \pm 0.13$ & $3.46 \pm 0.14$ \\
\hline $\mathrm{TG} /\left(\mathrm{mmol} \cdot \mathrm{L}^{-1}\right)$ & $0.27 \pm 0.03$ & $0.27 \pm 0.04$ & $0.26 \pm 0.04$ & $0.30 \pm 0.06$ \\
\hline
\end{tabular}

Note: $n$, number of ewes; TP, serum total protein; ALB, albumin; GLO, globulin; ALT, alanine aminotransferase; AST, aspartate aminotransferase; BUN, blood urea nitrogen; GLU, glucose; TG, triglyceride.

Table 3 The basic reproductive parameters of TG and WT ewes in $\mathrm{F}_{0}$ and $\mathrm{F}_{1}$

\begin{tabular}{|c|c|c|c|c|}
\hline \multirow{2}{*}{ Traits } & \multicolumn{2}{|c|}{$\mathrm{F}_{0}$} & \multicolumn{2}{|c|}{$\mathrm{F}_{1}$} \\
\hline & TG $(n=5)$ & WT $(n=5)$ & TG $(n=7)$ & WT $(n=6)$ \\
\hline $\begin{array}{l}\begin{array}{l}\text { Puberty } \\
\text { (days) }\end{array}\end{array}$ & $\begin{array}{c}143.91 \pm 6.14 \\
(132-151)\end{array}$ & $\begin{array}{c}145.05 \pm 5.28 \\
(128-149)\end{array}$ & $\begin{array}{c}145.44 \pm 6.14 \\
(131-153)\end{array}$ & $\begin{array}{c}144.05 \pm 4.28 \\
(135-149)\end{array}$ \\
\hline $\begin{array}{l}\text { Estrus cycle } \\
\text { (days) }\end{array}$ & $\begin{array}{c}17.05 \pm 1.31 \\
(15-19)\end{array}$ & $\begin{array}{c}17.87 \pm 0.36 \\
(16-18)\end{array}$ & $\begin{array}{c}17.42 \pm 0.94 \\
(16-20)\end{array}$ & $\begin{array}{c}17.55 \pm 0.99 \\
(16-18)\end{array}$ \\
\hline $\begin{array}{l}\text { Estrus duration } \\
\text { (hours) }\end{array}$ & $\begin{array}{c}33.65 \pm 2.45 \\
(24-39)\end{array}$ & $\begin{array}{c}32.9 \pm 3.53 \\
(19-40)\end{array}$ & $\begin{array}{c}32.65 \pm 3.31 \\
(18-41)\end{array}$ & $\begin{array}{c}34.01 \pm 4.13 \\
(17-38)\end{array}$ \\
\hline $\begin{array}{l}\text { Gestation } \\
\text { (days) }\end{array}$ & $\begin{array}{c}148.47 \pm 1.15 \\
(145-153)\end{array}$ & $\begin{array}{c}151.95 \pm 1.29 \\
(146-155)\end{array}$ & $\begin{array}{c}148.41 \pm 1.67 \\
(144-152)\end{array}$ & $\begin{array}{c}150.95 \pm 1.22 \\
(144-153)\end{array}$ \\
\hline Total pregnancy rate $/ \%$ & $100 \%(5 / 5)$ & $100 \%(5 / 5)$ & $100 \%(7 / 7)$ & $100 \%(6 / 6)$ \\
\hline
\end{tabular}

Note: $n$, number of ewes.

Table 4 Superovulation response of TG and WT ewes in $\mathrm{F}_{0}$ and $\mathrm{F}_{1}$

\begin{tabular}{lccccc}
\hline Superovulation parameters & & & & \multicolumn{2}{c}{$\mathrm{F}_{1}$} \\
\cline { 2 - 3 } \cline { 5 - 6 } & $\mathrm{TG}(n=4)$ & $\mathrm{WT}(n=4)$ & & $\mathrm{TG}(n=4)$ & $\mathrm{WT}(n=4)$ \\
\hline Average no. of corpora lutea & $12.33 \pm 2.80$ & $15.26 \pm 1.48$ & & $16.37 \pm 3.42$ & $14.91 \pm 1.77$ \\
Average no. of oocytes recovered & $8.50 \pm 1.12$ & $11.31 \pm 1.83$ & & $14.84 \pm 2.15$ & $13.44 \pm 0.91$ \\
\hline
\end{tabular}

Note: $n$, number of ewes; no., number.

compromised [14]. Variation in the hematological and biochemical characteristics of the blood can reflect the health of the animal [28]. In this study, the hematological parameters of the TLR4 transgenic ewes were found to be within the normal ranges. This suggested that transgenic sheep blood has the normal function of transportation and immune activity and that the blood sugar, blood fat, liver function, and renal function of transgenic sheep were normal. Similarly, a previous study found that there were no significant difference in physiological or biochemical blood characteristic between overexpressing Capra hircus $T L R 2$ and wild-type goats [29]. The hematological findings of the current study allow the preliminary inference that the TLR4 transgenic ewes were healthy according to the measured parameters. Given this finding, we further evaluated whether the TLR4 transgene could influence the reproductive traits of the ewes and the DNA methylation level of the oocytes. The monitoring results indicated that the TLR4 transgene showed no adverse effect on the reproductive performance of the ewes. To our knowledge, this study represents the first comprehensive reproductive assessment of transgenic ewes.

In the present study, the primary reproductive traits of the transgenic ewes were similar to those of the wild-type ewes. These traits included puberty, the estrus cycle, the duration of estrus, the superovulation response, the total pregnancy rate and gestation. These results suggest that the TLR4 transgene had no adverse effect on reproductive 


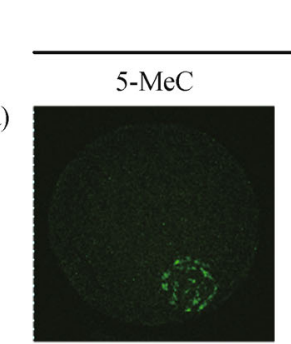

TG oocytes

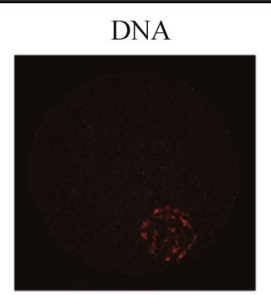

(b)

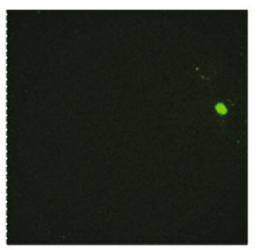

(c)

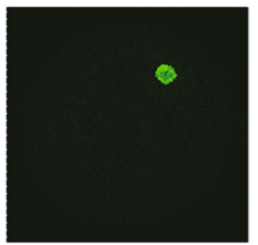

(d)

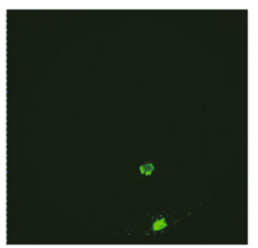

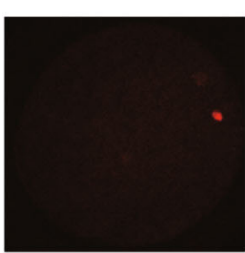

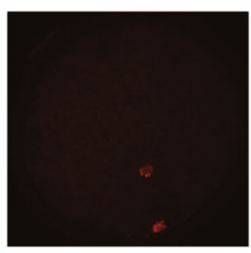

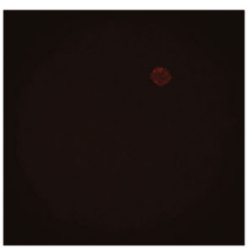
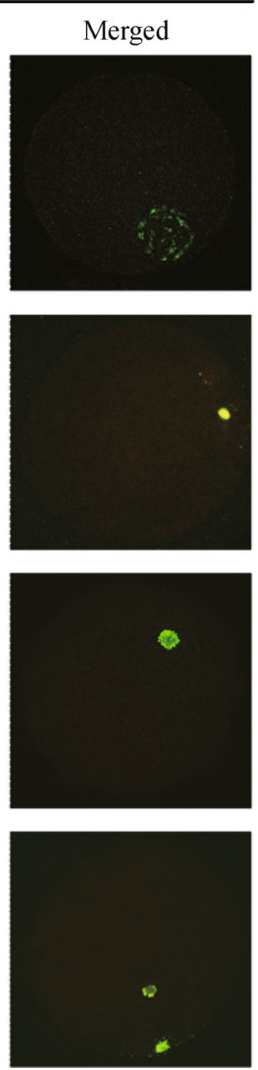

WT oocytes
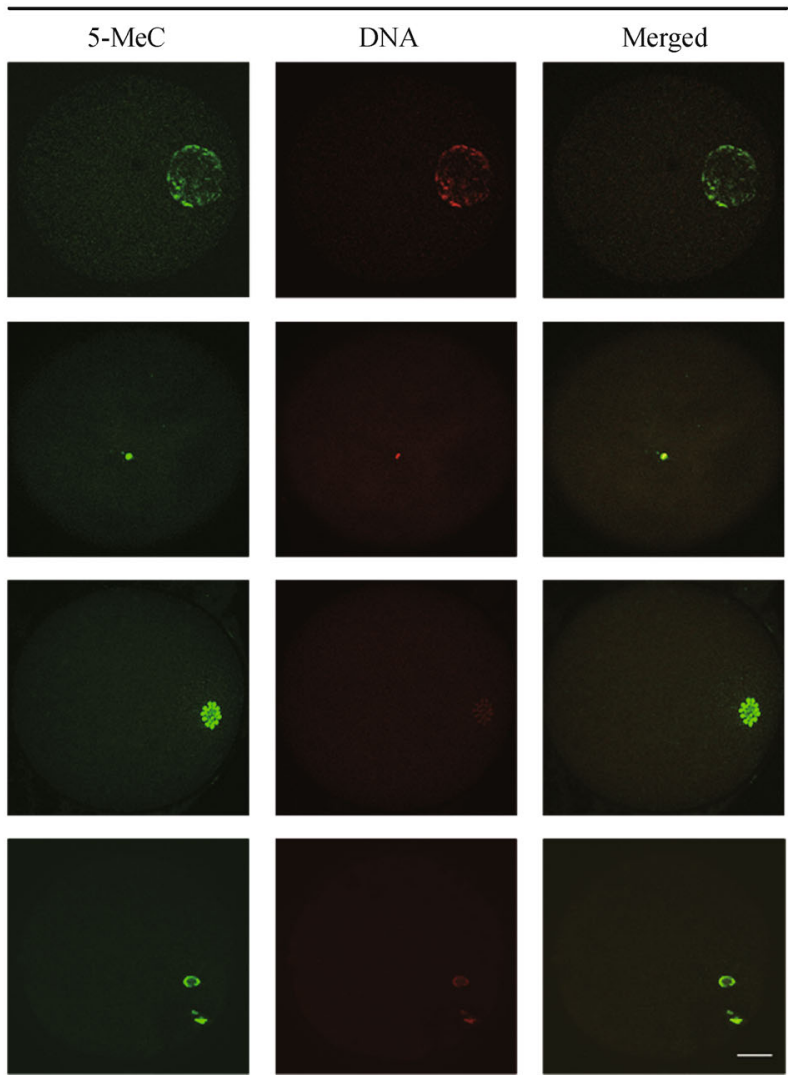

Fig. 1 Typical picture of 5-MeC patterns in TG and WT oocytes. (a) -(d) Immunofluorescence results on stage GV, GVBD, MI and MII oocytes, respectively. 5-MeC: FITC conjugated, green; DNA: PI stained, red; Merged: 5-MeC and DNA. Bar $=20 \mu \mathrm{m}$.

(a)

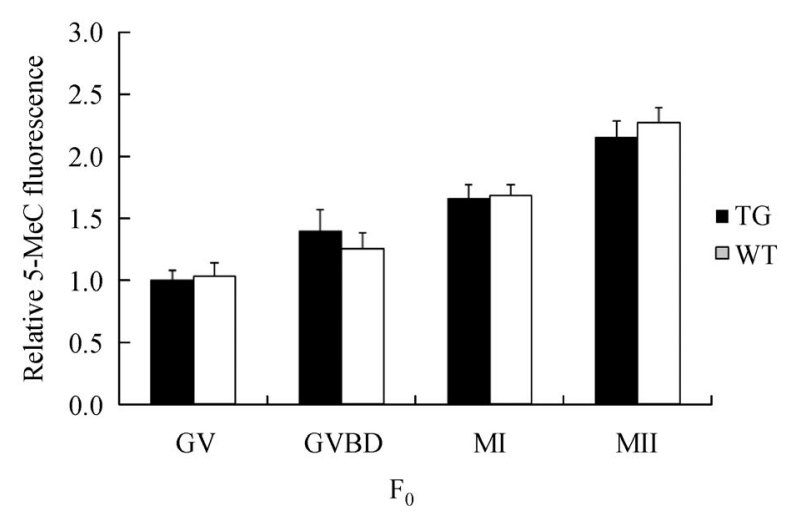

(b)

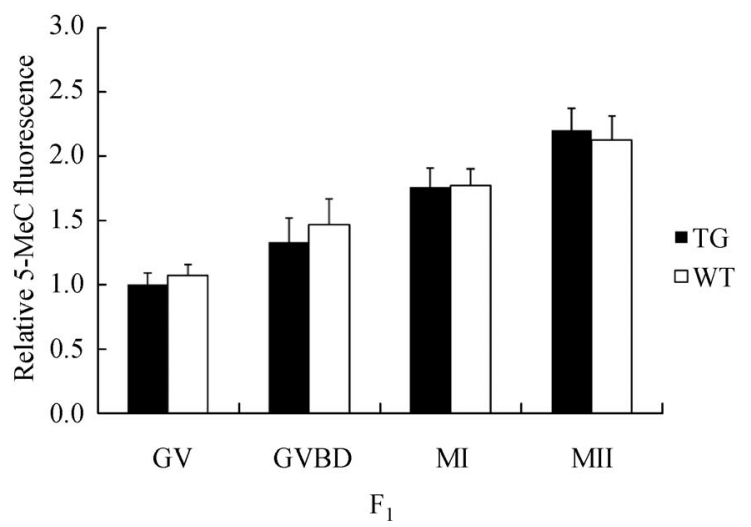

Fig. 2 Effect of TLR4 transgene on global DNA methylation levels in oocytes at various stages in $\mathrm{F}_{0}$ and $\mathrm{F}_{1}$. The average fluorescent intensity of GV oocyte from TG group was set as 1 in (a) and (b).

performance. Many transgenic animals, e.g., GFP transgenic pigs $[14,30]$ and human lysozyme transgenic sheep [8], have been produced, but few negative impacts on reproductive performance have been observed. Interactions between the immune system and the reproductive system have important consequences for fertility and reproductive health in general [31,32]. The TLR4 gene is closely associated with ovulation, fertilization, pregnancy and delivery in animals and can activate the innate immune system against reproductive diseases $[33,34]$. Therefore, the TLR4 transgene not only improves the disease resistance of the transgenic ewe $[33,35]$ but also ensures 
normal reproductive performance.

The interactions of endogenous and exogenous genes might cause unexpected epigenetic modifications in DNA [1], as frequently reported in studies of mice [16]. Thus, transgenic technology may change the stable equilibrium state of the genome and cause unpredictable effects, including abnormal DNA methylation patterns, via unknown mechanisms [10]. In this study, no abnormal changes were observed in the DNA methylation level of oocytes from the GV to MII stage in the $F_{0}$ and $F_{1}$ transgenic ewes. In addition, the trend in the variation of the level of methylation from the GV to the MII stage in the $F_{0}$ and $F_{1}$ transgenic group was consistent with that of the wild-type group. This result was most likely to be related to the unique pattern of DNA methylation in oocytes. Epigenetic maintenance mechanisms might be important in DNA methylation and reprogramming processes in oocytes [36].

\section{Conclusions}

No evidence of abnormal changes in blood physiological and biochemical parameters, reproductive traits or oocyte DNA methylation was found in $\mathrm{F}_{0}$ and $\mathrm{F}_{1} T L R 4$ transgenic ewes. These results represent a preliminary demonstration that the TLR4 transgene has no adverse effect on reproductive health.

\begin{abstract}
Acknowledgements This study was supported by key special projects for breeding new varieties of genetically engineered organisms in China (2011ZX08011-004). We thank Dr. Guangbin Zhou (Sichuan Agricultural University, China) and Nature Publishing Group Language Editing (NPGLE) for proofreading the manuscript.
\end{abstract}

Compliance with ethics guidelines Yi Fang, Xiangwei Fu, Junjie Li, Ming Du, Baoyu Jia, Jinlong Zhang, Xiaosheng Zhang and Shien Zhu declare that they have no conflict of interest or financial conflicts to disclose.

All applicable institutional and national guidelines for the care and use of animals were followed.

\section{References}

1. Doblhoff-Dier O, Collins C H. Biosafety: future priorities for research in health care. Journal of Biotechnology, 2001, 85(2): 227239

2. Clark J, Whitelaw B. A future for transgenic livestock. Nature Reviews Genetics, 2003, 4(10): 825-833

3. Einsiedel E F. Public perceptions of transgenic animals. Revue Scientifique et Technique, 2005, 24(1): 149-157

4. Van Reenen C G, Meuwissen T H, Hopster H, Oldenbroek K, Kruip T H, Blokhuis H J. Transgenesis may affect farm animal welfare: a case for systematic risk assessment. Journal of Animal Science, 2001, 79(7): 1763-1779

5. van der Meer M, Rolls A, Baumans V, Olivier B, van Zutphen L F. Use of score sheets for welfare assessment of transgenic mice. Laboratory Animals, 2001, 35(4): 379-389
6. Webster J. The assessment and implementation of animal welfare: theory into practice. Revue Scientifique et Technique, 2005, 24(2): 723-734

7. Food and Agriculture Organization (FAO). Safety assessment of foods derived from genetically modified animals, including fish. Rome: Report of the FAO/WHO Expert Consultation, 2004, 79: 136

8. Jackson K A, Berg J M, Murray J D, Maga E A. Evaluating the fitness of human lysozyme transgenic dairy goats: growth and reproductive traits. Transgenic Research, 2010, 19(6): 977-986

9. Brundige D R, Maga E A, Klasing K C, Murray J D. Lysozyme transgenic goats' milk influences gastrointestinal morphology in young pigs. The Journal of Nutrition, 2008, 138(5): 921-926

10. Brundige D R, Maga E A, Klasing K C, Murray J D. Consumption of pasteurized human lysozyme transgenic goats' milk alters serum metabolite profile in young pigs. Transgenic Research, 2010, 19(4): 563-574

11. Tang M, Zheng X, Cheng W, Jin E, Chen H, Yang S, Cui W, Li K. Safety assessment of $s$ Fat-1 transgenic pigs by detecting their cohabitant microbe in intestinal tract. Transgenic Research, 2011, 20 (4): 749-758

12. Xu J, Zhao J, Wang J, Zhao Y, Zhang L, Chu M, Li N. Molecularbased environmental risk assessment of three varieties of genetically engineered cows. Transgenic Research, 2011, 20(5): 1043-1054

13. Zhao J, Xu J, Wang J, Zhao Y, Zhang L, He J, Chu M, Li N. Impacts of human lysozyme transgene on the microflora of pig feces and the surrounding soil. Journal of Biotechnology, 2012, 161(4): 437-444

14. Huber R C, Remuge L, Carlisle A, Lillico S, Sandøe P, Sørensen D $\mathrm{B}$, Whitelaw C B, Olsson I A. Welfare assessment in transgenic pigs expressing green fluorescent protein (GFP). Transgenic Research, 2012, 21(4): 773-784

15. Deppenmeier S, Bock O, Mengel M, Niemann H, Kues W, Lemme E, Wirth D, Wonigeit K, Kreipe H. Health status of transgenic pigs expressing the human complement regulatory protein CD59. Xenotransplantation, 2006, 13(4): 345-356

16. Maga E A, Murray J D. Welfare applications of genetically engineered animals for use in agriculture. Journal of Animal Science, 2010, 88(4): 1588-1591

17. Cao Z, Li Y, Wen X, Li Z, Mi C, Zhang Z, Li N, Li Q. Recloned transgenic pigs possess normal reproductive performance and stable genetic transmission capacity. Zygote, 2014, 22(1): 18-24

18. Merlino G T, Stahle C, Jhappan C, Linton R, Mahon K A, Willingham M C. Inactivation of a sperm motility gene by insertion of an epidermal growth factor receptor transgene whose product is overexpressed and compartmentalized during spermatogenesis. Genes \& Development, 1991, 5(8): 1395-1406

19. Pellas T C, Ramachandran B, Duncan M, Pan S S, Marone M, Chada K. Germ-cell deficient (gcd), an insertional mutation manifested as infertility in transgenic mice. Proceedings of the National Academy of Sciences of the United States of America, 1991, 88(19): 8787-8791

20. Soriano P, Gridley T, Jaenisch R. Retroviruses and insertional mutagenesis in mice: proviral integration at the Mov 34 locus leads to early embryonic death. Genes \& Development, 1987, 1(4): 366375

21. Oliveri R S, Kalisz M, Schjerling C K, Andersen C Y, Borup R, 
Byskov A G. Evaluation in mammalian oocytes of gene transcripts linked to epigenetic reprogramming. Reproduction, 2007, 134(4): 549-558

22. Kues W A, Schwinzer R, Wirth D, Verhoeyen E, Lemme E, Herrmann D, Barg-Kues B, Hauser H, Wonigeit K, Niemann H. Epigenetic silencing and tissue independent expression of a novel tetracycline inducible system in double-transgenic pigs. The FASEB Journal, 2006, 20(8): 1200-1202

23. Hofmann A, Kessler B, Ewerling S, Kabermann A, Brem G, Wolf E, Pfeifer A. Epigenetic regulation of lentiviral transgene vectors in a large animal model. Molecular Therapy, 2006, 13(1): 59-66

24. Reik W, Römer I, Barton S C, Surani M A, Howlett S K, Klose J. Adult phenotype in the mouse can be affected by epigenetic events in the early embryo. Development, 1993, 119(3): 933-942

25. Reik W, Dean W, Walter J. Epigenetic reprogramming in mammalian development. Science, 2001, 293(5532): 1089-1093

26. Yue M, Fu X, Zhou G, Hou Y, Du M, Wang L, Zhu S. Abnormal DNA methylation in oocytes could be associated with a decrease in reproductive potential in old mice. Journal of Assisted Reproduction and Genetics, 2012, 29(7): 643-650

27. Takeda K, Akira S. Toll-like receptors in innate immunity. International Immunology, 2005, 17(1): 1-14

28. Borjesson D L, Christopher M M, Boyce W M. Biochemical and hematologic reference intervals for free-ranging desert bighorn sheep. Journal of Wildlife Diseases, 2000, 36(2): 294-300

29. Deng S, Yu K, Zhang B, Yao Y, Liu Y, He H, Zhang H, Cui M, Fu J,
Lian Z, Li N. Effects of over-expression of TLR2 in transgenic goats on pathogen clearance and role of up-regulation of lysozyme secretion and infiltration of inflammatory cells. BMC Veterinary Research, 2012a, 8(1): 196

30. Garrels W, Holler S, Cleve N, Niemann H, Ivics Z, Kues W A. Assessment of fecundity and germ line transmission in two transgenic pig lines produced by sleeping beauty transposition. Genes, 2012, 3(4): 615-633

31. Jungi T W, Farhat K, Burgener I A, Werling D. Toll-like receptors in domestic animals. Cell and Tissue Research, 2011, 343(1): 107-120

32. Kannaki T R, Shanmugam M, Verma P C. Toll-like receptors and their role in animal reproduction. Animal Reproduction Science, 2011, 125(1-4): 1-12

33. Müller M, Brem G. Transgenic approaches to the increase of disease resistance in farm animals. Revue Scientifique et Technique, 1998, 17(1): $365-378$

34. Girling J E, Hedger M P. Toll-like receptors in the gonads and reproductive tract: emerging roles in reproductive physiology and pathology. Immunology and Cell Biology, 2007, 85(6): 481-489

35. Deng S, Wu Q, Yu K, Zhang Y, Yao Y, Li W, Deng Z, Liu G, Li W, Lian Z. Changes in the relative inflammatory responses in sheep cells overexpressing of toll-like receptor 4 when stimulated with LPS. PLOS ONE, 2012a, 7(10): e47118

36. Li E. Chromatin modification and epigenetic reprogramming in mammalian development. Nature Reviews Genetics, 2002, 3(9): $662-673$ 